\title{
BUDIDAYA SAYURAN DENGAN TEKNIK PERTANIAN VERTIKULTUR DEMI TERCIPTANYA KETAHANAN PANGAN RUMAH TANGGA DI LAHAN SEMPIT
}

\author{
Risma Rusniati ${ }^{1}$, Firzatulloh Irhab Kautsar ${ }^{2}$, Ramadhina Nurdianti ${ }^{3}$, Kusumaningdyah \\ Nurul Handayani ${ }^{4}$
}

\author{
${ }^{1}$ Program Studi Penyuluhan dan Komunikasi Pertanian, Universitas Sebelas Maret Surakarta \\ ${ }^{2}$ Program Studi Ilmu Hukum, Universitas Sebelas Maret Surakarta \\ ${ }^{3}$ Program Studi Ilmu Tanah, Universitas Sebelas Maret Surakarta \\ ${ }^{4}$ Program Studi Arsitektur, Universitas Sebelas Maret Surakarta \\ Email: kusumaningdyah_nh@staff.uns.ac.id
}

\begin{abstract}
The increasing number of people who are not accompanied by the expansion of the area in Delanggu Village has resulted in reduced land for farming to meet food needs independently. The majority of the yards owned by residents in this village have an average area of $3 \mathrm{~m} 2$ which is relatively narrow. Vegetable cultivation with vertical farming techniques is one solution to overcome these problems. This cultivation can be done on vertical media so it does not require a large area. The purpose of this activity is so that the community can meet their food needs in the form of vegetables independently so as to create household food security. The service activity was carried out in Tegalsari Hamlet, Delanggu Village which was attended by 17 PKK members, 9 cloud community members and 6 teenagers. The community service method is carried out in stages, namely: preparation of tools and materials, socialization of efforts to create food security through vegetable cultivation with verticulture farming techniques and the correct way of vegetable cultivation starting from seeding, care and harvesting, and finally monitoring participants via WhatsApp and offline. From the series of activities, the participation and enthusiasm of the participants was quite good. PKK members apply it more, because they have more time at home compared to the general public and youth groups.
\end{abstract}

Keywords: Verticulture, Food Security, Vegetable Cultivation, Community Service

\begin{abstract}
ABSTRAK
Meningkatnya jumlah penduduk yang tidak dibarengi dengan perluasan wilayah di Desa Delanggu mengakibatkan berkurangnya lahan untuk bercocok tanam guna memenuhi kebutuhan pangan secara mandiri. Mayoritas lahan perkarangan yang dimiliki oleh warga di desa ini memiliki rata-rata luasan $3 \mathrm{~m}^{2}$ yang tergolong sempit. Budidaya sayuran dengan teknik pertanian vertikultur merupakan salah satu solusi untuk mengatasi permasalahan tersebut. Budidaya ini dapat dilakukan pada media vertikal sehingga tidak membutuhkan lahan yang luas. Tujuan dari kegiatan ini agar masyarakat dapat mencukupi kebutuhan pangan berupa sayuran secara mandiri sehingga tercipta ketahanan pangan rumah tangga. Kegiatan pengabdian dilaksanakan di Dukuh Tegalsari, Desa Delanggu yang diikuti oleh 17 anggota PKK, 9 orang masyarakat awam dan 6 orang remaja. Metode pengabdian masyarakat dilakukan secara bertahap, yaitu: persiapan alat dan bahan, sosialisasi mengenai upaya terciptanya ketahanan pangan melalui budidaya sayuran dengan teknik pertanian vertikultur dan cara budidaya sayuran yang benar mulai dari pembibitan, perawatan dan panen, serta yang terakhir yaitu monitoring peserta melalui WhatsApp dan luring. Dari rangkaian pelaksanaan kegiatan, partisipasi dan antusiame peserta cukup baik. Anggota PKK lebih banyak mengaplikasikannya, dikarenakan mempunyai lebih banyak waktu di rumah dibandingkan dengan kelompok masyarakat umum dan remaja.
\end{abstract}

Kata Kunci: Vertikultur, Ketahanan Pangan, Budidaya Sayuran, Pengabdian Masyarakat

\section{PENDAHULUAN}

Desa Delanggu adalah sebuah desa yang dikenal sebagai penghasil beras terbaik di Indonesia. Beras Rojolele menjadi kebanggaan daerah pada jaman dahulu dengan ciri khasnya yang pulen, enak, mengenyangkan serta faktor utama pendukungnya adalah luas wilayah daerah pada masa itu. Pertumbuhan penduduk yang tidak dibarengi dengan perluasan wilayah menyebabkan produksi beras tersebut berkurang dan menghilang seiring dengan berjalannya waktu. Sehingga 
penduduk dituntut untuk kreatif dalam memenuhi kebutuhan pangan selain mengandalkan produksi padi terbaik di lahan luas yang mulai hilang, kemudian berganti pada tanaman pangan atau sayur pada luasan lahan yang sempit. Desa Delanggu memiliki luasan wilayah sebesar 137.1250 Ha dengan populasi sementara penduduk sebanyak 5.905 yang meningkat disetiap tahunnya. Berdasarkan monografi Desa Delanggu tahun 2020 tercatat memiliki 11 RW (Rukun Warga), dan disetiap RW (Rukun Warga) memiliki RT (Rukun Tetangga) dengan populasi yang berbeda-beda. RW (Rukun Warga) 08 tercatat memiliki 4 RT (Rukun Tetangga) dengan jumlah populasi penduduk paling tinggi di Desa Delanggu yaitu sebanyak 304 kepala keluarga. Jumlah kepala keluarga tersebut paling padat penduduk di RT (Rukun Tetangga) 04 yakni Dukuh Tegalsari Delanggu, Kecamatan Delanggu sebanyak 92 kartu keluarga.

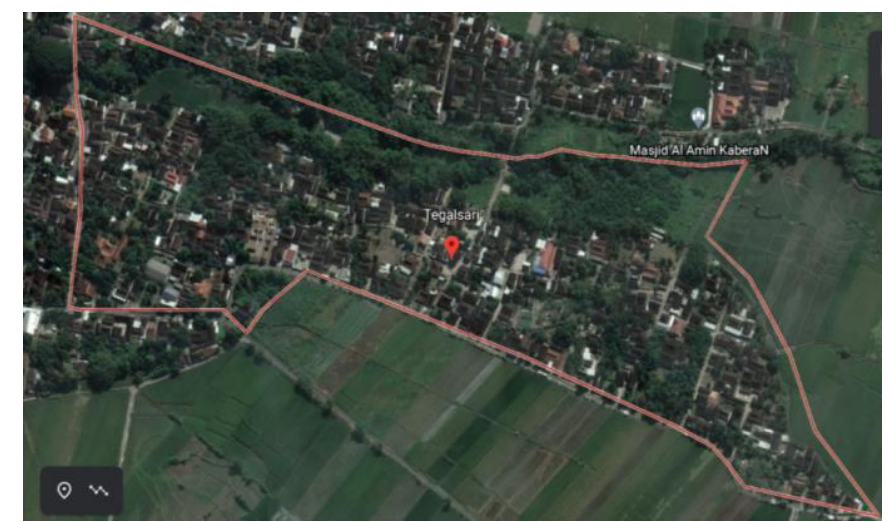

Gambar 1

Peta lokasi Dukuh Tegalsari Delanggu tempat Pengabdian Masyarakat Sumber: Google Earth, 2021

Pemukiman wilayah Tegalsari Delanggu terlihat sangat padat jarak antar rumah yang dimiliki setiap warga. Sehingga rata-rata memiliki pekarangan rumah dibawah $3 \mathrm{~m}^{2}$ bahkan beberapa tidak mempunyai pekarangan karena dinding rumah berdampingan langsung dengan rumah tetangga yang lain. Keadaan ini membuat warga tidak bisa dengan leluasa bercocok tanam guna memenuhi kebutuhan pangan keluarganya secara mandiri. Prabowo (2010) menyatakan bahwa kebutuhan pangan merupakan kebutuhan paling mendasar bagi manusia. Bercocok tanam dan penghijauan juga dinilai penting di samping untuk memenuhi kebutuhan sehari-hari secara mandiri dapat diperlukan sebagai sumber oksigen manusia untuk hidup lebih sehat. Oleh karena itu, cara efektif untuk tetap bisa bercocok tanam dan penghijauan di lahan terbatas guna memenuhi kebutuhan pangan sangat diperlukan di Tegalsari Delanggu.

Budidaya tanaman secara vertikultur menjadi alternatif yang efektif di Desa Tegalsari, Delanggu. Waupun kegiatan vertikultur umumnya diterapkan di area perkotaan. Hal ini dikarenakan teknik budidaya ini bisa lebih memaksimalkan areal pekarangan rumah mereka pada saat pandemi Covid-19 terjadi dimana mengharuskan mereka lebih banyak beraktifitas di rumah. Selain itu, kegiatan ini menjadi efektif karena memiliki pemanfaatan memaksimalkan nilai efficacy terhadap penggunaan barang bekas di lingkungan sekitar rumah. Nilai efficacy barang yaitu memperpanjang fungsi barang bekas untuk memiliki kebermanfaatan yang baru. Salah satunya menggunakan botol bekas kaca untuk menjadi media tanam vertikultur.

Rasapto (2006) menyatakan bahwa vertikultur dapat diartikan sebagai suatu sistem budidaya pertanian yang dilakukan dengan cara bertingkat atau menyusun tanaman ke arah atas (vertikal) 
yang dapat dilakukan di dalam ruangan atau luar ruangan. Teknik budidaya ini biasa digunakan di perkotaan dan lahan terbatas, misalnya pada lahan 1 meter yang hanya bisa untuk menanam 5 batang tanaman, dengan sistem vertikultur bisa digunakan untuk menanam 20 batang tanaman. Sihombing, Susilawati, and Sinaga (2019) menyatakan bahwa dalam proses membuat budidaya ini bisa dilakukan dengan menggunakan bahan-bahan bekas sekitar, dapat berupa bambu, pipa paralon, aqua bekas dan tali penghubung atau penyangga sehingga hemat biaya pada pembuatan. Pada proses memelihara/monitoring teknik budidaya vertikultur tidak perlu melalukan pengolahan tanah, tidak membutuhkan air yang banyak dan sedikitnya gulma karena tempat yang terjangkau.

Sistem vertikultur di Indonesia mulai dikembangkan pada tahun 1987. Penerapan sistem pertanian ini diharapkan dapat menambah produksi para petani terkait terkendalanya proses alih fungsi lahan. Priyono (2017) menyatakan bahwa teknik ini sudah banyak dikembangkan oleh masyarakat perkotaan seperti di Negara Jepang. Masyarakat Jepang sangat tekun dan ulet dalam membudidayakan tanaman-tanaman organik dengan teknik vertikultur, sebab pada umumnya lahan perkotaan di Jepang sangat sempit, sehingga sulit untuk membuka alih fungsi lahan baru. Beberapa jenis tanaman yang dapat di budidayakan dengan sistem vertikultur diantaranya tanaman jenis sawi, selada, kangkung, seledri. Oleh karenanya untuk memaksilmalkan intensifikasi lahan perkarangan warga di masa Pandemi Covid-19 serta adanya unsur pemanfaatan barang bekas di area permukiman warga maka sangat memungkinkan teknik budidaya vertikultur bisa menjadi solusi yang solutif proses beradaptasi warga pada masa Pandemi Covid-19. Vertikultur secara umum merupakan teknik berkebun secara bertingkat dengan dapat menanam sebanyak lebih dari 20-30 tanaman di tempat yang memiliki ukuran 50 $\mathrm{cm}$ x $50 \mathrm{~cm}$. Arifin (1998) menyatakan bahwa berdasarkan pengelompokan luas pekarangan adalah sempit $(<120 \mathrm{~m} 2)$, sedang $(120-400 \mathrm{~m} 2)$, besar $(400-1000 \mathrm{~m} 2)$, dan sangat besar $(>1000$ $\mathrm{m} 2$ ). Secara ekologis, ukuran paling minimal pekarangan yang dapat mencangkup keberagaman vertikal dan horizontal adalah $100 \mathrm{~m} 2$, sedangkan masyarakat Tegalsari Delanggu rata-rata memiliki pekarangan rumah dibawah $3 \mathrm{~m}^{2}$. Adanya pekarangan sempit disebabkan oleh fragmentasi pekarangan akibat adanya sistem pewarisan, pembagian rumah, dan jual beli lahan. Elemen yang ditemukan pada pekarangan Tegalsari Delanggu adalah elemen fisik berupa, tempat menjemur, kandang ternak, lubang tabunan, air, jalan desa dan tanaman.

Diadakannya sosialisasi dan penerapan budidaya sayuran dengan teknik vertikultur di Dukuh Tegalsari Delanggu Desa Delanggu oleh tim KKN 195 UNS diharapkan dapat menjadi solusi beradaptasi warga pada masa Pandemi Covid-19 dengan dapat memenuhi kebutuhan pangan keluarga secara mandiri. Hidayati, Rosawanti, Arfianto, and Hanafi (2018) menyatakan bahwa tidak menutup kemungkinan dari kegiatan ini dapat menghasilkan nilai tambah perekonomian keluarga apabila dikerjakan secara serius. Sehingga, sayuran dapat diproduksi secara mandiri dengan mudah. Budidaya vertikultur yang melibatkan ibu-ibu PKK, remaja dan warga umum selain berdampak kepada terpenuhinya kebutuhan pangan rumah tangga juga sebagai nilai edukasi bagi warga Tegalsari Delanggu yang sebagian besar baru mengenal teknik vertikultur ini yang cocok diterapkan di pekarangan sempit warga dengan banyak manfaat yang ditawarkan.

\section{METODE PELAKSANAAN PKM}

Kegiatan pengabdian masyarakat ini dilaksanakan pada tanggal 22 Agustus 2021 bertempat di posko KKN Tegalsari Delanggu pada pukul 10:00 sampai dengan 15:00 WIB. Kegiatan melibatkan kelompok Ibu-Ibu PKK sebanyak 17 partisipan, masyarakat awam sebanyak 9 partisipan dan remaja sebanyak 6 partisipan. Keseluruhan tahapan pelaksanaan kegiatan di Tegalsari Delanggu melalui proses Observasi (pengamatan), Ceramah dan Monitoring. 
Observasi dilakukan untuk mengetahui potensi dan permasalahan di lapangan. Tahapan ceramah dilakukan dengan metode sosialisasi program. Supini (2021) menyatakan bahwa metode kegiatan pengabdian masyarakat dalam bentuk sosialisasi mengenai bercocok tanam dengan teknik vertikultur ini adalah berwujud bekal pelatihan karena dengan pelatihan ini diharapkan masyarakat memiliki pengetahuan (knowledge) tentang vertikultur. Sedangkan tahapan diskusi dilakukan secara interaktif dua arah. Warga diminta aktif bertanya dan menilai proses yang dilakukannya. Tahapan yang terakhir berupa monitoring. Masyarakat diajak untuk mengevaluasi proses yang berlangsung. Apa yang menjadi keberhasilan dan kekurangan dalam budidaya vertikultur yang merka lakukan. Adapun kegiatan budidaya vertikultur ini terdiri dari 3 tahapan sebagai berikut:
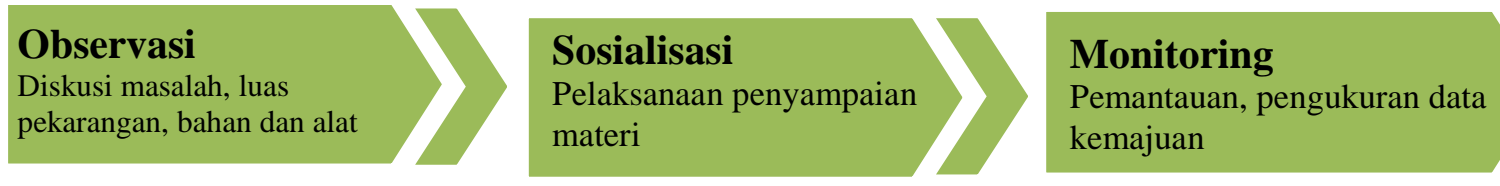

Gambar 2. Tahapan budidaya vertikultur

\section{HASIL DAN PEMBAHASAN}

Kegiatan Sosialisasi dan Edukasi Budidaya Sayuran melalui Vertikultur untuk mewujudkan ketahanan pangan rumah tangga ini dirancang dengan berbagai bentuk kegiatan dan interaksi yang terbatas di masa pandemi Covid-19. Kegiatan sosialisasi ini berlangsung dengan tertib protokol kesehatan sesuai dengan anjuran pemerintah, mulai dari penggunaan masker, tempat cuci tangan dan jaga jarak.

\section{a. Persiapan Kegiatan}

Persiapan dalam kegiatan Sosialisasi dan Edukasi Budidaya Sayuran melalui Vertikultur untuk mewujudkan ketahanan pangan rumah tangga ini dibagi menjadi tiga tahapan. Pada tahap pertama Mahasiswa KKN UNS melakukan diskusi kecil bersama warga. Diskusi terlaksana bersama Bp. Suko selaku RT 04 Tegalsari Delanggu guna mendiskusikan permasalahan desa serta merancang program kerja yang relevan untuk diterapkan di Tegalsari Delanggu. Persiapan yang kedua mengumpulkan data-data mengenai luasan pekarangan warga setempat serta mendokumentasikannya. Pengumpulan dokumentasi foto dilakukan secara online melalui media WhatsApp dan offline dengan mendatangi rumah warga secara langsung sembari membagikan undangan sosialisasi. Data berupa dokumentasi dan luasan pekarangan warga yang akan mengikuti kegiatan Sosialisasi setelah dibagikan undangan. Terlihat pada Gambar 3 warga tidak mempunyai pekarangan rumah yang cukup luas, dikarenakan langsung berbatasan dengan rumah selanjutnya atau jalan desa. Tahap ketiga, melakukan kegiatan pengukuran luas rata-rata pekarangan warga dilakukan secara offline dan media WhatsApp, yaitu dengan menanyakan kepada warga yang akan mengikuti kegiatan Sosialisasi kegiatan budidaya sayuran melalui vertikultur. 


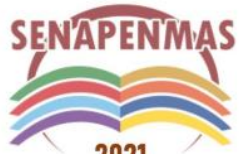

2021

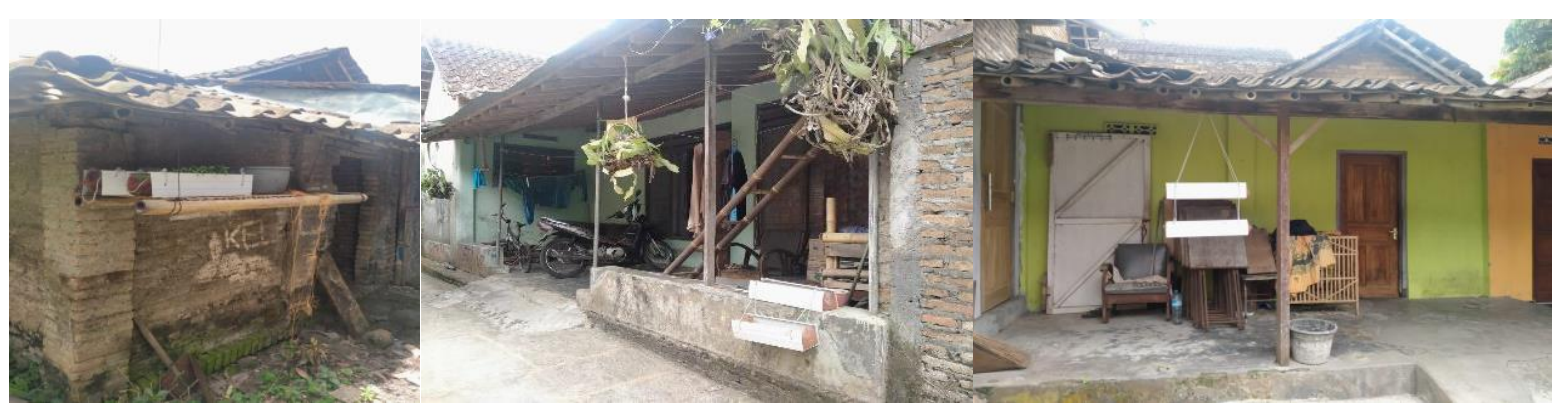

Gambar 3

Perkarangan pekarangan warga di Desa Tegalsari, Delanggu yang terbatas

Sumber: Dokumentasi Kegiatan KKN, 2021

Luas pekarangan menjadi aspek penting dalam bercocok tanam memenuhi kebutuhan pangan keluarga. Berdasarkan Tabel 1 rata-rata luas pekarangan warga yang mengikuti program sosialisasi KKN UNS pada tanggal 22 Agustus 2021 dengan hasil rata-rata yang diperoleh peserta yang akan mengikuti sosialisasi sesi 1 diambil 5 sampel memiliki rata-rata luas pekarangan sebesar 2,5 m. Pada sesi 2 yang akan mengikuti sosialisasi penanaman diambil 3 sampel memiliki luas lahan dengan rata-rata 3,5 m. Pada sesi 3 yang akan mengikuti sosialisasi penanaman setelah sosialisasi diambil 2 sampel memiliki rata-rata luas pekarangan sebesar 2,1 m. Dapat diketahui rata-rata luas pekarangan warga paling sempit berada pada sesi ke 1 sebesar 2,5 m, luas pekarangan terbesar berada pada sesi ke 2 sebesar $3,5 \mathrm{~m}$. total rata-rata dari sampel sebanyak 8,1 m dengan 3 dari 10 warga yang tidak memiliki pekarangan $(0 \mathrm{~m})$.

Tabel 1. Rata-rata Luas Pekarangan Warga

\begin{tabular}{ccc}
\hline Sesi & Sampel & Rata-rata Luas Pekaranangan \\
\hline 1 & $(1,5 \times 1)(0)(0)(0)(1 \times 1)$ & $2,5 \mathrm{~m}$ \\
\hline 2 & $(1 \times 1)(1 \times 0,5)(2 \times 1)$ & $3,5 \mathrm{~m}$ \\
\hline 3 & $(2 \times 2)(0,5 \times 0,5)$ & $2,1 \mathrm{~m}$ \\
\hline Jumlah & $10,25 \mathrm{~m}$ & $8,1 \mathrm{~m}$ \\
\hline
\end{tabular}

Sumber: Data Primer

Tahap persiapan alat dan bahan dilaksanakan di posko KKN bertempat di salah satu rumah warga yang biasa dijadikan untuk perkumpulan acara desa. Alat yang digunakan berupa paralon persegi yang digunakan sebagai wadah media tanam berukuran $40 \mathrm{~cm}$, beserta tali berbahan tali tukang atau tali pramuka yang dipasangkan pada setiap ujung paralon dan jaring tipis sebagai penutup samping paralon. Paralon dibagikan kepada setiap orang dengan jumlah 2 buah menyesuaikan media tanam yang dipakai. Sedangkan untuk bahan tanaman sayuran berupa bibit kangkung, cabai, bayam, selada, sawi yang dibungkus dengan plastik klip. Fachmawati (2019) menyatakan bahwa jenis-jenis tanaman yang dibudidayakan biasanya adalah tanaman yang memiliki nilai ekonomi tinggi, berumur pendek atau tanaman semusim khususnya sayuran (seperti seledri, caisism, pack-choy, baby kalian, dan selada), dan memiliki sistem perakaran yang tidak terlalu luas. Dilengkapi dengan media tanam berupa tanah siap pakai 2 karung plastik 
setiap satu orang pengguna. Persiapan dilakukan dengan membungkus dalam satu wadah berisi media tanam, bibit sayuran dan paralon yang siap dibagikan kepada warga pada saat sosialisasi.
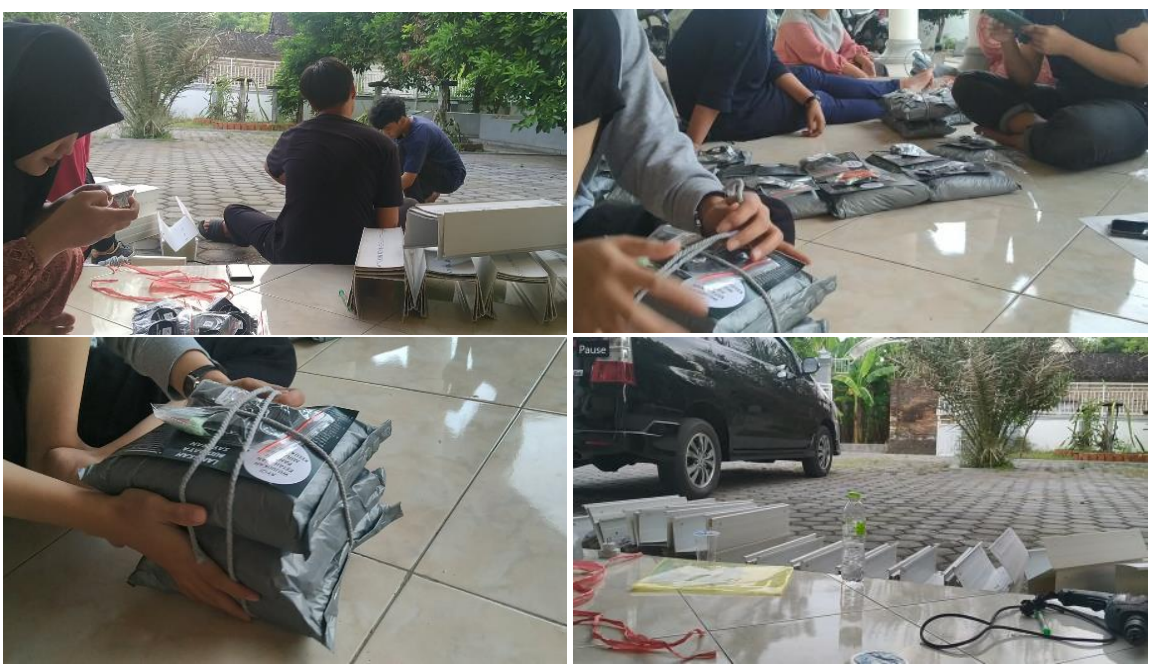

Gambar 4

Persiapan bahan-bahan dan alat kebutuhan sosialisasi dan pelatihan vertikultur Sumber: Dokumentasi Kegiatan KKN, 2021

\section{b. Sosialisasi}

Sosialisasi dan Edukasi Budidaya Sayuran melalui Vertikultur untuk mewujudkan ketahanan pangan rumah tangga dilaksanakan pada tanggal 22 Agustus 2021. Penyampaian materi disertai dengan media penyuluhan sebagai penjelas informasi yang disampaikan berupa leaflet yang dibagikan dan power point yang ditampilkan. Serta membawakan demplot vertikultur sebagai alat peraga dalam sosialisasi. Sosialisasi diawali dengan pemaparan materi mengenai pentingnya menciptakan ketahanan pangan rumah tangga secara mandiri. Materi dipilih berdasarkan permasalahan pokok warga Tegalsari Delanggu selama pandemi yang menyebabkan banyak rumah tangga kehilangan pendapatan, sehingga berkurang kemampuan untuk memenuhi dan menciptakan ketahanan pangan rumah tangga. Materi yang disampaikan berupa pentingnya upaya mewujudkan ketahanan pangan rumah tangga pada masa pandemi Covid-19 dengan cara memanfaatkan lahan pekarangan rumah yang terbatas. Materi tentang cara budidaya yang benar mulai dari proses pembibitan, perawatan dan panen serta pengenalan teknik pertanian vertikultur disampaikan untuk mendukung masyarakat dalam mewujudkan ketahanan pangan rumah tangga. Kemudian dilanjutkan dengan pembagian paket budidaya tanaman sayur dan edukasi mengenai cara budidaya tanaman sayuran.

Alat yang disediakan oleh tim KKN berupa paralon persegi yang sudah dipotong berukuran 40 $\mathrm{cm}$ sebagai wadah media tanam, selain menggunakan paralon warga dapat menggunakan botol minuman bekas sehingga barang dapat didaur ulang dengan memanfaatkan penggunaan sebagai wadah media tanam juga dapat menggunakan bambu termasuk salah satu tanaman di Tegalsari Delanggu yang mudah di temukan serta cocok digunakan untuk wadah media tanam yang disusun secara vertikal. Jenis tanaman yang dipilih berupa sayuran berumur pendek (kangkung, cabai, bayam, selada dan sawi) selain mudah dalam perawatannya juga kelima sayuran tersebut sering dikonsumsi oleh warga Tegalsari Delanggu sehingga sayuran dapat dikonsumsi sendiri ataupun menjadi nilai tambahan ekonomis apabila lebih dalam hasil panen. Sedangkan media tanam yang dibagikan berupa tanah dengan komposisi 50\% srintil kambing, 25\% sekam padi dan $25 \%$ tanah, selain media tanam yang sudah disiapkan tersebut warga dapat dengan mudah 
menggunakan tanah disekitar lahan sempitnya untuk diambil dimasukkan ke dalam botol bekas, bambu atau paralon beserta perbandingan 2:1:1 dengan pupuk organik, sekam padi dan tanah. Kegiatan diakhiri dengan diskusi dan sharing mengenai hambatan yang pernah ditemui ketika menanam sayuran dengan antusias dan semangat peserta.
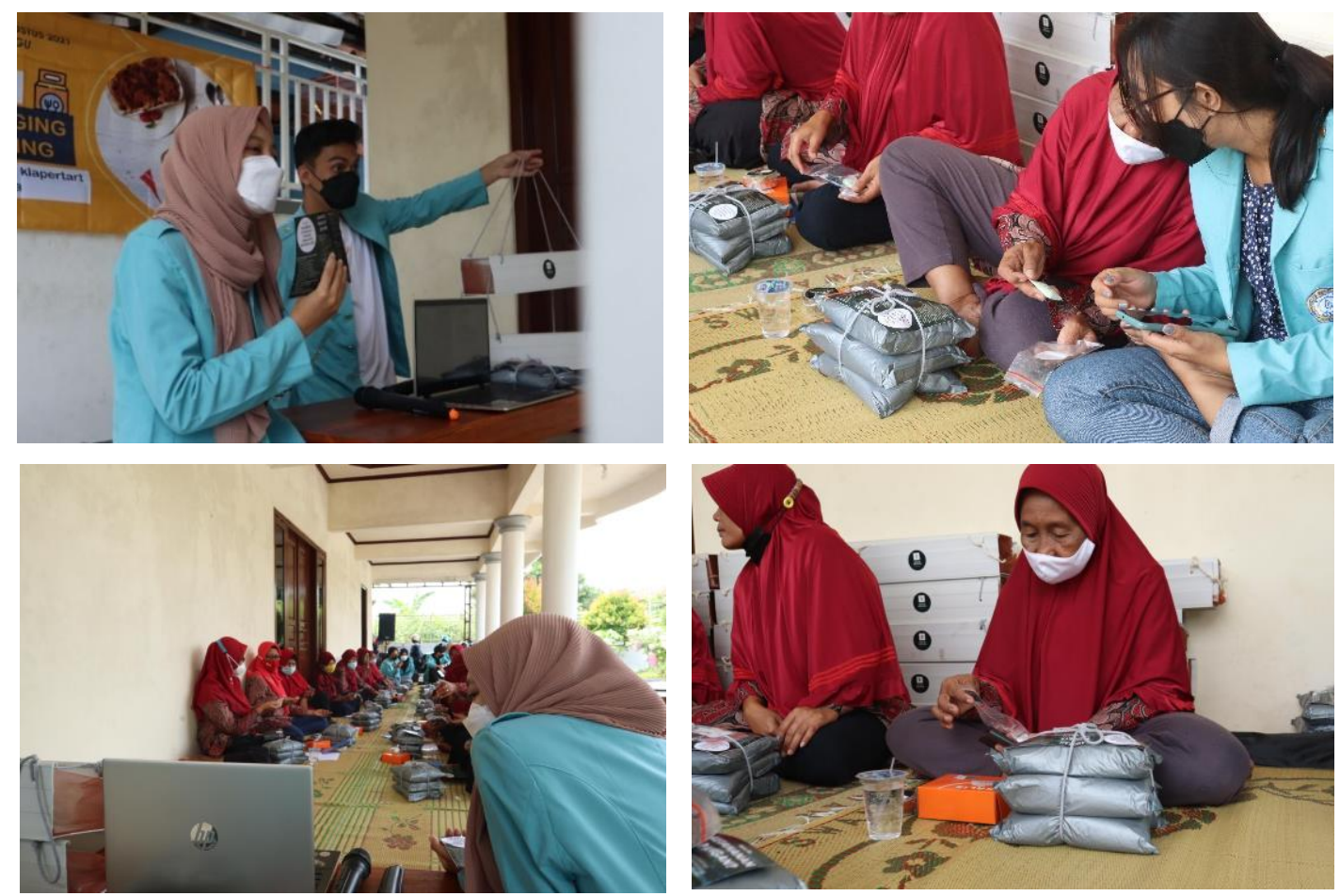

Gambar 5

Sosialisasi dan edukasi budidaya sayuran melalui vertikultur

Sumber: Dokumentasi Kegiatan KKN, 2021

Mengingat kondisi di era Covid-19, pembatasan berskala besar masih berjalan, maka dari itu sosialisasi dibagi menjadi 3 sesi dalam satu hari. Berdasarkan Tabel 2 sosialisasi budidaya sayuran dengan teknik pertanian vertikultur dilaksanakan dalam 3 sesi pada hari yang sama. Sesi pertama dilaksanakan pada pukul 10.00 WIB dengan 17 peserta dari ibu-ibu PKK Dukuh Tegalsari Desa Delanggu. Sesi kedua dilaksanakan pada pukul 13.00 WIB dengan 9 peserta dari masyarakat umum Dukuh Tegalsari Desa Delanggu. Sesi ketiga dilaksanakan pada pukul 14.00 WIB dengan 6 peserta dari remaja Dukuh Tegalsari Desa Delanggu. Jumlah peserta yang menghadiri acara sosialisasi secara keseluruhan adalah 32 orang.

\section{Tabel 2}

Jumlah data Status Peserta Tiap Sesi

\begin{tabular}{cclc}
\hline No & No dan Waktu Sesi & \multicolumn{1}{c}{ Jenis Paritisipan Kelompok } & Jumlah Peserta \\
\hline 1 & Sesi 1: 10.00 WIB & Anggota PKK Dukuh Tegalsari Desa Delanggu & 17 \\
\hline 2 & Sesi 2: 13.00 WIB & $\begin{array}{l}\text { Masyarakat RT 01 dan RT 04 Dukuh Tegalsari } \\
\text { Desa Delanggu }\end{array}$ & 9 \\
\hline 3 & Sesi 3: 14.00 WIB & Remaja Dukuh Tegalsari, Desa Delanggu & 6 \\
\hline Jumlah Peserta & & 32 \\
\hline
\end{tabular}

Sumber: Data Primer Lapangan 


\section{c. Monitoring}

Kegiatan Monitoring dilakukan untuk menghitung berapa jumlah peserta yang menerapkan budidaya sayuran dengan teknik pertanian vertikultur. Monitoring dilakukan secara luring dan daring dengan menghubungi peserta melalui WhatsApp yang dilakukan oleh Koordinator KKN Kelompok 195 sekaligus warga Dukuh Tegalsari, Desa Delanggu. Peninjauan dilakukan untuk menindak lanjuti program sosialisasi yang telah diikuti. Monitoring melalui media WhatsApp dilakukan secara berkelanjutan dengan menanyakan dan berdiskusi mengenai pertumbuhan tanaman yang sudah ditanam, baik dari bayam, kangkung dan tanaman yang didapat setelah sosialialisasi. Hasil dari monitoring menunjukkan beberapa tanaman dapat tumbuh dengan lebat pada daunnya, beberapa sudah dipanen sayurnya untuk dimasak, namun ada juga yang terserang hama sehingga tanaman mati sebelum penangan penyembuhan.
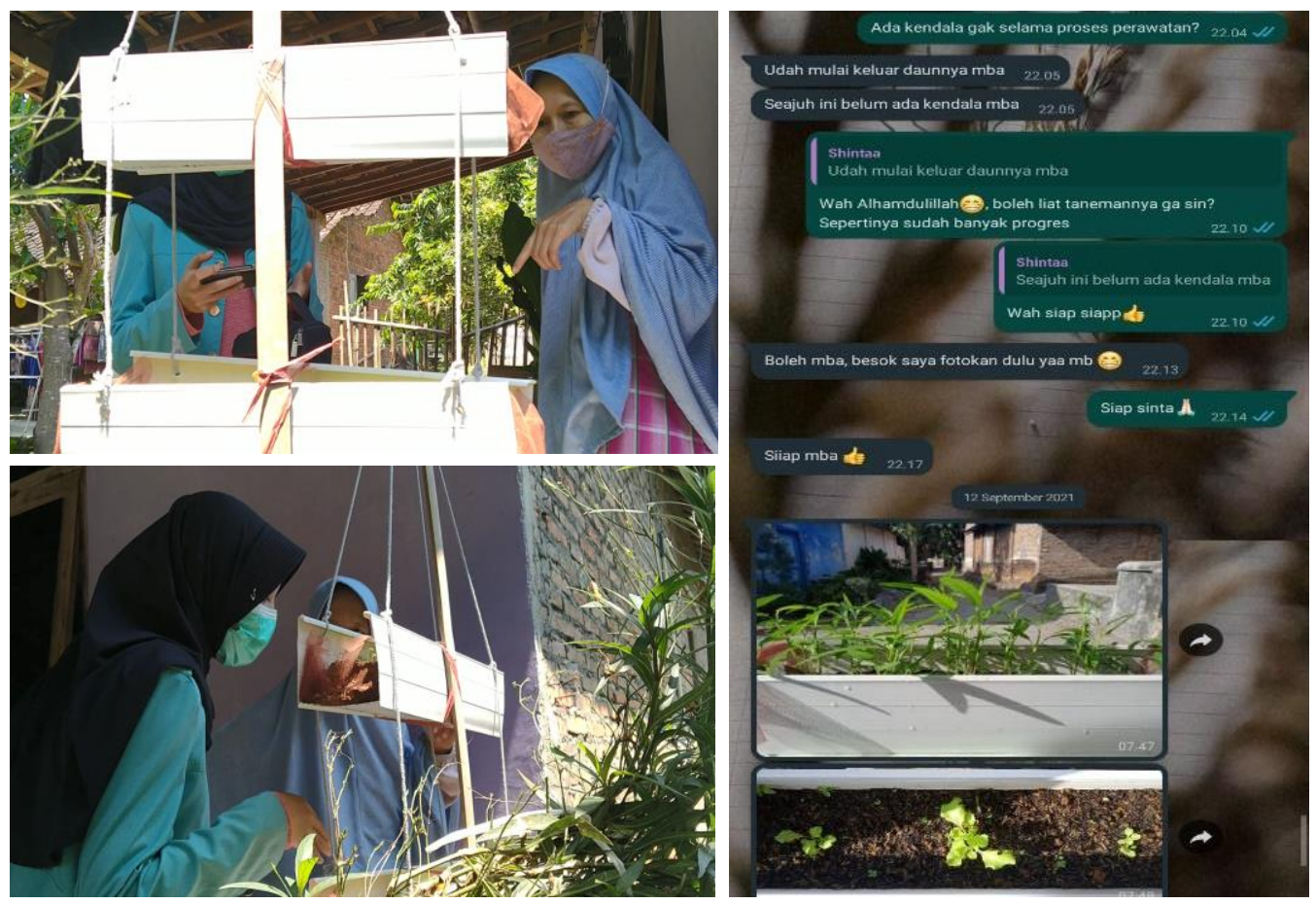

Gambar 6.

Monitoring daring dan luring

Sumber: Dokumentasi Kegiatan Lapangan, 2021

Berdasarkan hasil monitoring yang dipaparkan pada Tabel 3 jumlah peserta yang paling banyak mengaplikasikan hasil sosialisasi merupakan peserta sesi pertama beranggota ibu-ibu PKK Dukuh Tegalsari Desa Delanggu, yaitu sebanyak 10 orang. Sedangkan jumlah peserta yang paling sedikit mengaplikasikan hasil sosialisasi merupakan peserta dari sesi terakhir yang merupakan remaja Dukuh Tegalsari Desa Delanggu. Selain jumlah peserta yang hadir paling banyak, pada kelompok Ibu PKK lebih banyak mengaplikasikan karena mayoritas anggota memiliki waktu luang lebih banyak daripada kelompok lain. 
Tabel 3

Jumlah peserta yang mengaplikasikan teknik pertanian vertikultur

\begin{tabular}{lc}
\hline \multicolumn{1}{c}{ No, Waktu Sesi dan Jenis Partisipan } & $\begin{array}{c}\text { Jumlah Peserta Yang Mengaplikasikan } \\
\text { dari Jumlah Partisipan Keseluruhan }\end{array}$ \\
\hline $\begin{array}{l}\text { Sesi 1: 10.00 WIB (Anggota PKK Dukuh Tegalsari Desa } \\
\text { Delanggu) }\end{array}$ & 10 dari 17 \\
\hline $\begin{array}{l}\text { Sesi 2: 13.00 WIB (Masyarakat RT 01 dan RT 04 Dukuh } \\
\text { Tegalsari, Desa Delanggu) }\end{array}$ & 5 dari 9 \\
\hline $\begin{array}{l}\text { Sesi 3: 14.00 WIB (Remaja Dukuh Tegalsari, Desa } \\
\text { Delanggu) }\end{array}$ & 3 dari 6 \\
\hline \multicolumn{1}{c}{ Jumlah } & 18 dari 32 \\
\hline
\end{tabular}

\section{Sumber: Data Primer}

Dengan perbandingan jumlah peserta yang hadir dan yang mengaplikasikan sebagai berikut. Berdasarkan Grafik 1 peserta yang mengaplikasikan hasil sosialisasi pada masing-masing sesi berjumlah setengah atau lebih dari jumlah peserta yang hadir. Sedangkan keseluruhan peserta yang mengaplikasikan hasil sosialisasi sebesar 56, 25\% atau sebanyak 18 orang. Dapat disimpulkan 18 dari 32 orang atau lebih dari setengah setiap kelompok mau dan mampu menerapkan teknik vertikultur untuk bercocok tanam dilahan sempit warga.

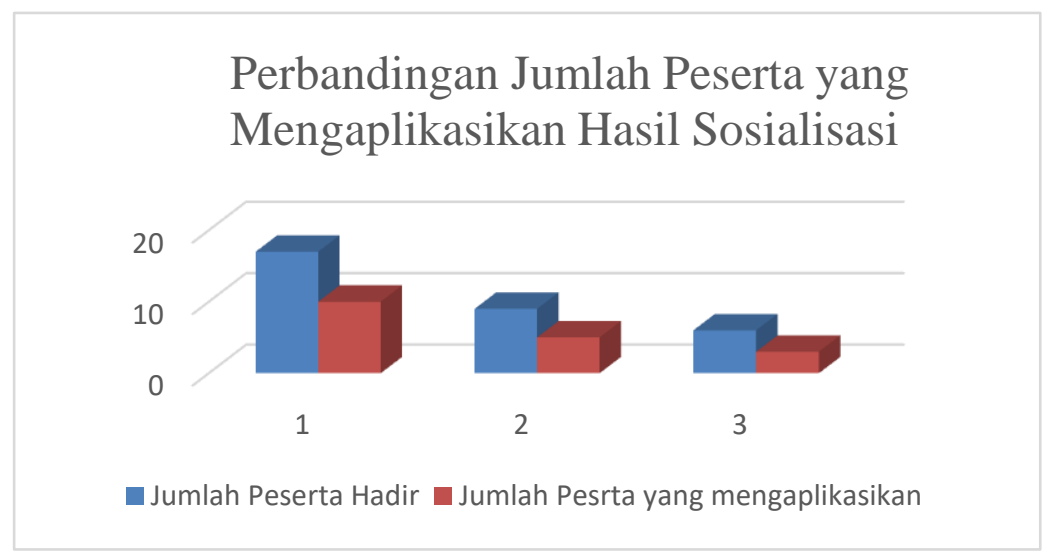

\section{Grafik 1}

Perbandingan jumlah peserta yang hadir dan mengaplikasikan hasil sosialisasi Sumber: Data Primer

\section{DAMPAK}

Dampak dari kegiatan sosialisasi ini yaitu masyarakat Dukuh Tegalsari Desa Delanggu mampu bercocok tanam sayuran di lahan perkarangan rumah yang sempit masing-masing. Diharapkan mampu mencukupi kebutuhan bahan pangan berupa sayuran secara mandiri. Manfaat lain yang dapat diperoleh yaitu mengurangi pengeluaran untuk membeli sayur, mendapatkan sayuran yang lebih sehat, menciptakan ketahanan pangan rumah tangga bahkan menambah pendapatan rumah tangga apabila sayur tersebut diperjual belikan. Apabila ingin dijadikan kegiatan komersil, pemanfaatan lahan pekarangan dapat dikembangkan dengan pendekatan konsep nanosociopreneur; yang berangkat dari hal-hal kecil dan diharapak memberikan dampak pada manfaat besar dalam ruang lingkup yang lebih luas (Muttaqin \& Sari, 2017). Pelaksanaan 
budidaya sayuran di pekarangan dapat dilakukan secara kolaboratif untuk memenuhi kebutuhan warga sehingga dapat menunjang ketahanan pangan nasional (Kusumo, et al, 2020)

\section{KESIMPULAN DAN SARAN}

Adapun kesimpulan dari kegiatan Sosialisasi dan Edukasi Budidaya Sayuran melalui Vertikultur untuk mewujudkan ketahanan pangan rumah tangga sebagai berikut:

1. Kegiatan pengabdian dilaksanakan dengan tiga tahapan yaitu observasi dan proses persiapan kegiaatan, tahapan sosialisasi sekaligus didalamnya terdapat diskusi dua arah antara partisipan dan pemateri serta tahapan monitoring yang bertujuan sebagai metode evaluasi keberhasilan program sosialisasi dan edukasi budidaya sayuran melalui vertikultur.

2. Para peserta kegiatan di Dukuh Tegalsari, Desa Delangu mempunyai antusias belajar yang baik. Adab belajar nampak dengan memperhatikan materi yang disampaikan dan berdiskusi dua arah pada sesi tanya jawab. Tercatat sebannyak 18 dari 32 peserta yang hadir pada kegiatan ini telah menerapkan teknik budidaya vertikultu pada pekarangan rumah mereka masing-masing.

3. Keberhasilan pelaksanaan program pengabdian melalui edukasi dan pelatihan budidaya sayuran dengan teknik pertanian vertikultur kepada anggota PKK, masyarakat umum dan remaja ini memberikan manfaat antara lain: dapat mengurangi pengeluaran untuk membeli sayuran, mendapatkan sayuran yang lebih sehat, menciptakan ketahanan pangan rumah tangga bahkan menambah pendapatan rumah tangga apabila sayur tersebut diperjualbelikan. Serta tercatat 56, 25\% atau 18 dari 32 peserta menerapkan teknik vertikultur setelah sosialisasi mengindikasikan keberhasilan program.

\section{Ucapan Terima Kasih}

Ucapan terima kasih penulis ucapkan kepada Allah SWT yang telah memberikan kemudahan dalam segala kegiatan ini. Ucapan terima kasih juga disampaikan kepada Universitas Sebelas Maret (UNS) Surakarta, Unit Pelaksanaan Kuliah Kerja Nyata (UPKKN), Lembaga Penelitian dan Pengabdian Kepada Masyarakat (LPPM) UNS Surakarta yang telah memfasilitasi pelaksanaan kegiatan KKN periode Juli-Agustus 2021. Dan yang paling utama penulis mengucapkan banyak terimakasih serta apresiasi setinggi-tingginya kepada Dosen Pembimbing Lapangan, Dr Eng Kusumaningdyah N.H yang telah mendampingi serta memberi solusi dari setiap kegiatan ini berlangsung. Secara khusus apresiasi dan ucapan terima kasih kepada masyarakat dan pemerintah Desa Delanggu atas partisipasi dan kerjasama yang baik selama kegiatan ini, juga anggota kelompok KKN 195 dalam menyelesaikan tugas. Atas dukungan, partisipasi dan kerja sama yang diberikan, kami dapat menyelesaikan tugas Kuliah Kerja Nyata Tematik periode Juli-Agustus 2021 sehingga berjalan dengan baik dan lancar.

\section{REFERENSI}

Arifin HS, Sakamoto K, Chiba K. (1998). Effects of urbanization home gardens on the vegetation Java, structure of in west Indonesia. Jpn J Trop Agr. 42(2): 94-102.

Fachmawati, I. (2019, Desembaer 12). Budidaya Pertanian di Lahan Sempit. Diakses dari http://cybex.pertanian.go.id/mobile/artikel/88107/BUDIDAYA-PERTANIAN-DILAHAN-SEMPIT/

Hidayati, N, P. Rosawanti, F. Arfianto, and N. Hanafi. (2018). "Pemanfaatan Lahan Sempit Untuk Budidaya Sayuran dengan Sistem Vertikultur". PengabdianMu, 3(1), 40 - 46.

Kusumo, R. A. B., Sukayat, Y., Heryanto, M. A., and Wiyono, S. N. (2020). "Budidaya sayuran dengan teknik vertikultur untuk meningkatkan ketahanan pangan rumah tangga di perkotaan”. Dhamakarya: Jurnal Aplikasi Ipteks untuk Masyarakat, 9(2), 89-92. 


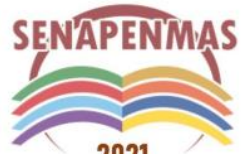

2021
Seminar Nasional Hasil Penelitian dan Pengabdian Kepada Masyarakat 2021 Pengembangan Ekonomi Bangsa Melalui Inovasi Digital Hasil Penelitian dan Pengabdian Kepada Masyarakat Jakarta, 21 Oktober 2021

Muttaqin, Z., and Sari, D. S. (2017). "Nanosociopreneur cengek: design thinking bisnis hijau berkelanjutan di desa saying kecamatan jatinangor". Dharmakarya: Jurnal Aplikasi Ipteks Untuk Masyarakat, 6(3), 254-257.

Prabowo, R. (2010). "Kebijakan pemerintah dalam mewujudkan ketahanan pangan di Indonesia". Mediagro, 6(2), 62-73.

Priyono, W. (2017, April 22). Cara Bertanaman Vertikultur, Cara Budidaya Tanaman di Lahan Sempit yang Menguntungkan. Diakses dari https://tipspetani.com/cara-bertanamvertikultur-cara-budidaya-tanaman-lahan-sempit-menguntungkan/

Rasapto W. (2006). Budidaya Sayuran Dengan Vertikultur. Jawa Tengah: Balai Pengkajian Teknologi Pertanian

Sihombing, Y. A. Susilawati, M. Z. Sinaga, (2019). "Introduction of verticulture technique for utilization of spring land in Madrasah Tsanawiyah (MTs) ibnu sina City of Pematang Siantar". Abdimas Talenta, 4 (1), 872-876.

Supini, E. (2021, Mei 6). Mengenal Teknik Vertikultur, Cara Bertanam di Lahan Sempit. Diakses dari https://paktanidigital.com/artikel/mengenal-teknik-vertikultur-cara-bertanamdi-lahan-sempit/\#.YWa5WhpBzb1 
Seminar Nasional Hasil Penelitian dan Pengabdian Kepada Masyarakat 2021

Pengembangan Ekonomi Bangsa Melalui Inovasi Digital Hasil Penelitian dan

Pengabdian Kepada Masyarakat

Jakarta, 21 Oktober 2021

(halaman kosong) 